inOedia $\quad \begin{aligned} & \text { InMedia } \\ & \text { The French Journal of Media Studies }\end{aligned}$

4 | 2013

Exploring War Memories in American Documentaries

\title{
"How Could You Forget That?": Representing Collective and Traumatic Memories in Winter Soldier
}

Daniel Grinberg

\section{(2) OpenEdition \\ Journals}

Electronic version

URL: http://journals.openedition.org/inmedia/674

DOI: 10.4000/inmedia.674

ISSN: 2259-4728

Publisher

Center for Research on the English-Speaking World (CREW)

\section{Electronic reference}

Daniel Grinberg, " "How Could You Forget That?": Representing Collective and Traumatic Memories in Winter Soldier », InMedia [Online], 4 | 2013, Online since 18 November 2013, connection on 08

September 2020. URL : http://journals.openedition.org/inmedia/674 ; DOI : https://doi.org/10.4000/ inmedia. 674

This text was automatically generated on 8 September 2020

(C) InMedia 


\section{"How Could You Forget That?": Representing Collective and Traumatic Memories in Winter Soldier}

Daniel Grinberg

\section{AUTHOR'S NOTE}

The author would like to thank Brett Bowles, Edward Bowen, Derek Horn, and the anonymous peer-reviewers for reading earlier drafts of this article and providing their valuable feedback.

"If one dude got up and rapped all this shit, they'd hang him," Scott Shimabukuro tells his fellow veterans in the 1972 documentary Winter Soldier. "But they can't deny the testimony of all these dudes in the room." Hoping to "remove the blinders and the blinds from in front of America's eyes," 116 veterans and 16 civilians gathered at Howard Johnson's New Center Motor Lodge in Detroit, Michigan on January 31 and February 1 and 2, 1971 to speak at the Vietnam Veterans Against The War's (VVAW) Winter Soldier Investigation hearings. ${ }^{3}$ Over those three days, the majority of these 132 individuals ${ }^{4}$ publicly testified to atrocities they participated in or witnessed in Vietnam from 1963 to 1970. They described rape, torture, murder, and massacres that John Kerry characterized as acts that were "committed on a day-to-day basis with the full awareness of officers at all levels of command. ${ }^{5}$ Yet, despite the significance of these cumulative recollections, nearly all of the journalists and television camera crews there neglected to report on it; the footage shot for Winter Soldier remains the only public audiovisual record of the event. ${ }^{6}$

2 In the following article, I propose that this documentary is an especially valuable historiographical text because its representations of memory reflect, critique, and, to a 
growing degree, help construct collective national memory. Through a close textual reading, I will demonstrate how the film links veterans' individual acts of recall to the larger lacunae of social and institutional remembrance. Incorporating historical documents and transcripts and the film's paratextual elements, I will also explicate how Winter Soldier, created by the nineteen-member Winterfilm Collective, itself constitutes a work of collective memory. Finally, by examining the documentary's reception-particularly its thirty-three-year delay in receiving widespread theatrical distribution and the thirty-four-year delay in the release of a home-viewing format-I will suggest how this visualization of atrocity can also be understood as a traumatic memory repressed within the national consciousness.

3 Fittingly, for a war characterized by disputed official accounts, contentious battles over monuments, and a post-war "decade-long amnesia," the lens of memory has made a substantial contribution to Vietnam War scholarship across disciplines. ${ }^{8}$ Memory as an analytic lens has also been notably applied to a diverse range of Vietnam War fiction films. ${ }^{9}$ However, considering Paula Rabinowitz's observation that "[d]ocumentary cinema is intimately tied to historical memory" and "often functions as an historical document itself," there has been surprisingly little scholarship specifically regarding memory and the Vietnam War documentary. ${ }^{10}$

In addition, in the late 1990s and early 2000s, a new wave of historical scholarship arose to reexamine the impact of the Winter Soldier investigations. ${ }^{11}$ As David Cortright noted in 2002, "After being misunderstood and overlooked for decades, the war resistance of soldiers and veterans is finally receiving the attention it deserves." ${ }^{12}$ Yet, presumably because of its decades-long lack of theatrical distribution and commercial availability, the documentary Winter Soldier is only mentioned tangentially in these accounts. Therefore, this article will strive to connect memory studies and documentary studies and demonstrate why this vital film merits more thorough scholarly consideration.

5 The rediscovery of this forty-one-year-old document is timely because of its lucid indictment of unchecked American military power. At a moment when the aftermath of the wars in Iraq and Afghanistan are still reverberating globally, the detention facility at Guantanamo Bay remains in operation in its eleventh year, and the Obama administration was recently advocating for military intervention in Syria, it is imperative to reassess the nuances of preceding conflicts like Vietnam for perspective. Though there are meaningful and well-documented distinctions between the wars in Vietnam and Iraq, the many disturbing parallels between the two also necessitate deeper investigations in how American-led wars are waged, archived, and recalled especially as the United States continues to engage in new conflicts. ${ }^{13}$ Furthermore, revisiting Winter Soldier, which centers on the testimonies and traumas of veterans, could simultaneously shed light on the precarious state of veteran services and the ongoing crises concerning veterans' mental and physical health. According to a comprehensive 2013 report conducted by the Department of Veterans Affairs Mental Health Services, veterans now commit suicide every 65 minutes or at a rate of 22 per day, an alarming statistic that should remind us of the danger of overlooking the physical and psychic repercussions of war. ${ }^{14}$ This figure also educes that the film is not the relic of a bygone era, but that it can instructively speak to fundamental contemporary issues. 


\section{Textual Representations of Memory}

6 I begin by analyzing how the film textually links individual and collective acts of memory. In particular, I want to demonstrate how it connects veterans' inabilities to recall specific incidents and the national desire to selectively forget the war. In one such emblematic instance of a memory lapse, the documentary shows Kenneth Campbell approaching fellow veteran Scott Camil during a pre-testimony interview. Campbell begins listing details of Camil's service and adds, "I thought I recognized you. I was sitting over there, trying to figure out who the hell you were, man." Campbell asks Camil if he knows about "a ville wiped out, in Quang Tri," prompting the latter man to volunteer, "Yeah, I was there. ... The first thing we do was burn down the village and kill everybody." Despite the horrific nature of this offensive, Camil marvels, "I didn't even remember that. . . I I forgot all about that one." Campbell's incredulous response is perhaps even more illustrative of the complex and thorny nature of memory: "How could you forget that? I remember it and I wasn't even in on it."

7 Tellingly, Camil only remembers this event when Campbell questions him about it. Camil shows a clear willingness to investigate this memory further, saying, "Whenever they're questioning me, they'll have to get me to elaborate on that." In a subsequent direct address to the camera, he also states that he finds discussing these traumatic recollections therapeutic, but he has difficulty locating people outside of the university system who will listen. When trying to openly communicate with his family, for instance, Camil notes, "[T] hey all say 'you're crazy ... how can you think like that?" Because, as James Pennebaker and Becky Banasik observe, "language is a social act" and verbalizing an event "can influence the way the event is organized in memory and, perhaps, recalled in the future," Camil's lack of recall exemplifies the civilian disinclination to engage his memories..$^{15}$ Because the act of hearing a memory verbalized can also prolong and intensify the memory for the listener, the civilians' avoidance of these conversations circumscribes their own fuller remembrances of the war as well. ${ }^{16}$ Yet, substantiating Camil's sentiments that "[i]t still bothers me sometimes" and "[I haven't] gotten it out of my system," Pennebaker and Banasik also observe, "When people do not want to or cannot openly talk about an important event, they continue to think and even dream about it. ... Ironically, then, actively trying not to think about an event can contribute to a collective memory in ways that may be as powerful if not more so than events that are openly discussed." 17

We encounter another lapse through William Hatton, a former Marine who reports carrying around a pistol "for no apparent reason" upon his return and pulling the weapon on a janitor in a fit of rage. As a result of this assault, Hatton says, "It came ... as a real surprise the stuff that just started coming back." Namely, he testifies to his participation in a group of Marines brutally stoning a Vietnamese boy to death. As photos of villager children running along roadsides appear onscreen, he admits, "We just smeared him. We just wiped him out. . . . It was looked upon as funny. We all laughed about it and then we forgot about it and it took me about a year to even be able to recall the situation." Although Hatton never explains this gap, it is retrospectively evident that his experience typifies symptoms of post-traumatic stress disorder. Known as post-Vietnam syndrome at the time, the most prominent aspect of this condition is that the memories of traumatic experiences remain inaccessible until various stressors or stimuli reactivate them and render them perceptible. ${ }^{18}$ 
9 The film makes clear that Hatton's repression is not remarkable or unique, but a pervasive occurrence among Vietnam veterans. As Hatton is testifying, the camera zooms out and shows him sitting among his fellow panelists. Although a few look over to him, most are so unfazed by his revelations that they evince no reaction. Moreover, the editing emphasizes the commonality of Hatton's experience by following it with James Duffy's statement about killing another Vietnamese boy. Duffy testifies:

My first reaction, and my flight engineer, he was observing this too, our first reaction was, I guess, you'd call normal. It would be horror, pain, and then I realized that I caught myself immediately and I said, 'No, you can't do that,' because you develop a shell while you are in the military. They brainwash you. They, they take all the humanness out of you, and you develop this crust which enables you to survive in Vietnam. And if you let that protective shell down, even for a second... it's the difference between you flipping out or managing to make it through. And I caught myself letting the shell down and I tightened up right away and started laughing about it and joking about it with the flight engineer, and he sort of moved on the same logic 'cause I guess ... it sort of knocked his shell down too.

Both Hatton and Duffy describe their repressions collectively, with the former saying, "we forgot about it" and the latter saying that he and the flight engineer shared "the same logic." Fred Turner observes, "Between 1959 and 1973, more than a million and a half Americans saw combat in Vietnam. When they came home, psychologists estimate that as many as 40 percent of them brought with them some form of post-traumatic stress disorder." ${ }^{19}$ Thus, these documented lapses, along with Camil's and numerous others, stand in for an epidemic of post-traumatic repressions.

11 I also argue that Hatton's yearlong lack of recall is metonymic of a larger national repression. Because the veterans were not only victims but also victimizers, performing mass slaughter under the American aegis, his lapse may be attributable to the effects of what Raya Morag calls "perpetrator trauma." ${ }^{20}$ Yet, since soldiers are authorized proxies of the nations that fund them and send them to fight, I believe that Hatton's repression also parallels a collective desire to evade "a concomitant acknowledgement of societal perpetration." ${ }^{21}$ Because the public watched a daily stream of news images of the conflict that Michael Arlen dubbed the "living-room war"22 and Michael Mandelbaum called "the television war," absorbing gruesome images that proffered a more constant and visceral experience of war than preceding media, viewers were also continually reminded of the consequences of their ancillary involvement. ${ }^{23}$ Thus, as Roger Silverstone posits, "If audiences refuse to take ... responsibility, then they are morally culpable. And we are all audiences now." ${ }^{24}$

In the film, we see sporadic glimpses of the Detroit audience watching the testimonies, but in one scene, while scanning the crowd, the camera zooms in and lingers on a crying woman. Her head is bent down and she is covering her face, as if to shield herself from witnessing any more or even to deny her presence. For me, she typifies what I call a traumatized 'citizen perpetrator,' simultaneously misled and complicit, both removed and involved. Regarding this phenomenon, Peter Marin writes, "None of us has faced the specter of his own culpability-not Nixon's, not Kissinger's-but the way in which each of us, actively or passively, contributed to the killing, the taxes we paid, officials we elected, the endless ... influences that made countless young men willing to kill." ${ }^{25}$ Jeffrey Jay notes, "The veteran's [psychological] conflicts are not his alone, but are bound to the trauma and guilt of the nation. And our failure to deal with our guilt renders the veteran the symptom-carrier for society." ${ }^{26}$ Robert Jay Lifton, the 
psychologist who popularized the term 'post-Vietnam syndrome,' also states, "Americans as a national group have become participants in, and survivors of, a sustained pattern of killing and dying ... . and we are left with the numbing and brutalization required to ... fend off a sense of guilt." ${ }^{27}$

We witness another revealing lapse in the opening scene of Winter Soldier. Conducting a pre-testimony interview, Joe Bangert asks veteran Rusty Sachs his age, prompting Sachs to look up and hesitantly reply, "Twenty- . . seven." When Bangert asks him to list his dates of service, his eyes squeeze shut before he answers, "August '66, September '67." Bangert then inquires if Sachs has ever witnessed "prisoners thrown from helicopters." Smiling widely, Sachs describes in evocative detail how men from his squadron "used to blindfold guys with safety wire and pull it real tight, so the copper wire is tearing into their eyes and nose" and "have contests to see how far they could throw the bound bodies out of the airplanes." Yet, when asked to approximate how many people he has seen killed this way, Sachs has trouble providing an estimate. "In the . . . two-digit numbers, say," he speculates. "Somewhere between fifteen and fifty probably."

14 As the exchange develops, the film suggests that Sachs' individual inability to remember the number of casualties results from sanctioned military policy. He says, "We were told, 'Do not count prisoners when loading 'em on board the aircraft. Count 'em when you unload 'em . . . because the numbers may not jibe."' By retroactively documenting these adjusted totals, the soldiers did not have to account for missing Vietnamese prisoners and could treat them as expendable non-entities. Sachs also states that "you never know" who is an enemy combatant or a civilian, but that all dead bodies are automatically counted in the former category. The film validates Sachs' assertion by including a later interview with Camil, in which he confirms that slippery statistics was standard practice. "You could've killed one enemy," he says, "and by the time it would get up to the high command ... you killed fifty of them, because they couldn't say they lost five men taking one. So the body count is a bunch of shit." Camil also mentions reading a newspaper account of an operation he participated in and finding intentionally incorrect figures meant to mislead "the people at home." In addition, we see Scott Moore testify that their accounting was:

A case of the colonels going into competition and making up more bodies than they really had. And this was, of course, passed on down to the company commanders, platoon leaders, and the squad leaders. So, hell, we were reporting stuff, water buffalo in some cases, and shadows. . . . Other firefights, the count would be 80,90 , and personally I only saw two, three bodies. So it's a totally inflated system. What's happened is, the American public's been lied to.

15 Cumulatively, the three men's statements demonstrate how inexact and biased official memory is in times of war. Roy Baumeister and Stephen Hastings note that "it is relatively easy and common to take some shreds of historical truth and blow them up into a major, important myth" and embellish "minor achievements into glorious triumphs." ${ }^{28}$ Grossly inflating the size of dead Viet Cong soldiers also allows the military to minimize its transgressions as necessary responses to the enemy or to attribute offenses it commits to this exaggerated aggressor. As Camil's experience with the newspaper suggests, even historiography and journalistic reporting may not convey accurate, objective retellings of these events. Because stories about the war 
frequently contained overstated figures, the American public, like Rusty Sachs, could no longer trust its recollection of statistics. When these numbers come into doubt, the accounts of events they undergird invariably become suspect and uncertain as well.

\section{A Critique of Historiography}

16 Winter Soldier bolsters its critique by textually connecting Vietnam War memorialization to other moments of selective remembering and forgetting within American historiography. It does this conspicuously with its title, a term created by VVAW members and adopted in 1971 during the hearings the film documents. ${ }^{29}$ The term inverts the opening lines of The American Crisis, the call-to-arms Thomas Paine wrote during the American Revolution: “These are the times that try men's souls: The summer soldier and the sunshine patriot will, in crisis, shrink from the service of his country; but he that stands it now, deserves the love and thanks of man and woman." 30 According to organizer William Crandell, "The identification with Paine's pamphlet marked the beginning of VVAW's self-awareness that ours was a revolutionary role, and it noted our embracing of the American tradition of revolution." ${ }^{31}$ The documentary foregrounds this connection from the first frame, displaying the film title and a copyright symbol dated 1972 as Winterfilm Collective member Rhetta Barron states, "In the winter of 1776, at Valley Forge, Tom Paine wrote...." Her oral evocation of "the winter of 1776" and the visualizations of "Winter" and "1972" conflate the two moments and juxtapose Detroit (and by extension, sites like Quang Tri and Saigon) with perhaps the most iconic battleground in American history.

However, by invoking such a pivotal moment, Barron's recitation of Paine's quote also ironizes the differences between the American Revolution and Vietnam and punctures our recollection of "the half-imagined, heavily mythologized America of the past." 32 Whereas in Paine's era, the eponymous "crisis" was the struggle to overthrow a colonizing power, the crisis in 1972 was the assertion of American imperialism in a foreign revolution. Furthermore, although Paine wrote his pamphlet to goad soldiers into fighting, the onscreen veterans are defined by their opposition to the Vietnam conflict. Thus, the documentary (via the organizers who selected the event name) revises Paine's intent, positing that the current revolutionary act in "the times that try men's souls" is not to wage war, but rather to remember the war and publicly testify to its atrocities.

The film's citation of Paine concurrently reminds us of history's capacity to forget and revise. Although Paine is now nationally heroized, he was an iconoclast who was ostracized during much of his lifetime. In Paine's final years, his rival William Cobbett wrote, "Like Judas he will be remembered by posterity." ${ }^{33}$ Craig Nelson notes that, for centuries, Paine was incorrectly "remembered as a filthy, poverty-stricken, drunken wastrel" because his views were "so provocative and so uncompromising that he faced the gibbet and the blade everywhere he published." ${ }^{34}$ Thus, by drawing on Paine's radically shifting commemoration, the film connotatively upholds the righteousness of the veterans' cause and argues that history will similarly vindicate their courage to speak out.

The documentary also includes numerous instances of non-white soldiers criticizing the racialized nature of historiography and their position in collective memory. In a heated debate occurring outside of the testimony, we see an unidentified black veteran 
object to the hearings' effacement of black history. When he tries to broach this discussion, another veteran defensively interjects, “We didn't say anything about race -" to which he replies, "No shit. That's how come you ain't got no black people behind you. Because you forgot about racism, man!" His protest reflects the rampant racial inequity in the American military, where African-Americans, averaging between 9 and 10 percent of the military personnel serving in Vietnam, were drafted at disproportionately high rates, were more likely to be placed in combat units, and suffered higher casualty rates..$^{35}$ While others audibly insist on a need for unity, the veteran urges them to recognize the singularity of the black struggle and implicitly educes the national legacies of slavery, segregation, and institutional discrimination. He says, "Being black is a deep thing. I know you get tired of hearing it, but it's some shit that is out there. The only way a brother can live when he get out of school, if he ain't got no smarts, is to go in the army, man.... We only have one or two outlets to go, man. You got three or four... . You got those variables. We don't."

The veteran also points out how mass media both reflect and shape racist myths and how they influence historical remembrance. He states, "I watch television whenever I get the chance. I don't watch for entertainment. You know what I watch? I watch all the whitewashing they throw on you everyday, man. Like, shit about Indians. Now they let the Indians win. But for years, they didn't. But, for years, when you was a little kid, you sucked that shit right up. That's what you believed the real shot was." We see Native American veteran Evan Haney similarly testify, "When I was small, I was exposed to this [racism]. ... [0]n television, when I watched the Indian and the cavalry, I would root for the cavalry." Such hegemonic renarrativizations efface uncomfortable events and minority perspectives and reinforce these distortions within public memory on a national scale. The Winterfilm documentarians note this tendency in the American televisual representation of Vietnam as well, writing, "The face of an enemy was not on the television screen. They were reportedly hiding in the jungles. But we saw many Vietnamese people. We saw dead and wounded bodies." ${ }^{36}$

21 The documentary also registers the erasure of Vietnamese memory, albeit primarily through its invisibility. The Winter Soldier organizers arranged to have Vietnamese war survivors "tell the people of the United States and Canada what we are doing to their country" via closed-circuit television in Windsor, Canada, but the Canadian government denied them visas. ${ }^{37}$ Consequently, no Vietnamese perspective appeared at the hearings and those recollections are likewise absent from the public record and the film. Instead, we hear Scott Camil relate how the Marines taught him to conceptualize his enemy, saying, “The Vietnamese were gooks. We didn't just call the VC, the NVA gooks. All Vietnamese were gooks and they were slant-eyes, zips, they were Orientals, and they were inferior to us." In his testimony, Dennis Caldwell also links the loss of Vietnamese memory to American intrusion, saying, "There were hundreds and hundreds of villages marked on the map I had with me, all kinds of names on the map, but you get over that area, and there's nothing there at all." Because, as Marita Sturken observes, "remembering is in itself a kind of forgetting," these soldiers' memories foreground their own experiences, threatening to supersede memories of the Vietnamese "in their roles as collaborators, victims, enemies, or simply the people on whose land and over whom (supposedly) this war was fought." ${ }^{38}$ 


\section{The Text as Collective Memory}

22 Along with the onscreen representations of memory, I argue that Winter Soldier itself constitutes a form of collective memory. Most evidently, there is the film's content and the event that it documents. VVAW organized the Winter Soldier hearings to coalesce the individual, fragmented recollections of veterans into a shared narrative and disseminate it to an unaware public. Mark Lenix justified his presence in Detroit as a representative of multitudes, saying, "[I]f I saw it, I'm sure there are a lot of veterans who aren't here who saw it," and Don Donner said his panel's testimonies would speak to "what the war has done to us individually and collectively." ${ }^{39}$ Explaining the hearings before the Senate Foreign Relations Committee in April 1971, John Kerry expressed that these voices also intended to influence future remembrances of Vietnam, remarking that "when thirty years from now our brothers go down the street without a leg, without an arm, or a face, and small boys ask why, we will be able to say 'Vietnam' and not mean ... a filthy obscene memory, but mean instead where America finally turned and where soldiers like us helped it in the turning." ${ }^{40}$

Documenting these memories, the footage we see onscreen also reveals that this putatively single film text is actually an assemblage of individual recordings. The diverse shooting styles of the documentarians remind us that Winter Soldier is the product of a nineteen-member group called the Winterfilm Collective and that no one camera or observer could have captured all of these varied perspectives. ${ }^{41}$ Describing the filmmaking process, Winterfilm member Roger Phenix says, "First thing we did was just look at everything. And that was the first point at which we all saw together what each other had seen individually and it was an incredibly bonding experience." ${ }^{42}$ The group's identification as a collective and their eight-month editing process involving "five or six people working at a time" and "many veterans giving input" further reflect their deliberately collaborative spirit. ${ }^{43}$ Their former insistence on anonymity and stilluncredited contributions also allow their work not only to stand for the group, but to epitomize the memories of the larger audience, evoking Michael Schudson's supposition that memory is not "a property of individual minds" but "most often [a] social and interactive" process. ${ }^{44}$ Yet, the necessary condensation of three days of testimony and interviews into more than 100 hours of footage and ultimately, a 95minute work also evinces that the documentary genre inherently remains a subjectively reduced and arranged representation of what Claude Lanzmann calls "traces of traces." 45

Unlike Amos Vogel who, in his 1972 review of Winter Soldier, contended, "[T]he work is ... primarily a social artifact, whose informational content outweighs its artistic merits," I argue that the documentary's sometimes raw aesthetics not only reflect but enhance the testimonies. ${ }^{46}$ The grainy, outdated black-and-white film the documentarians used because of their extremely limited funds gives the contemporaneous footage the feel of a recovered historical relic. If "the mimetic image claims to represent what is, in fact, unrepresentable," ${ }^{47}$ as Frances Guerin and Roger Hallas argue, then the low quality and lack of color of the footage here instead accentuates that the output of memory can substantially diverge from the input. The uneven lighting and awkward angles required to capture some of the impromptu conversations and overall cinéma vérité approach further confirm that audiovisual images, like memories, are not impartial or infallible, but marked with the conditions 
that catalyzed their creation. As Sharon Willis notes, film also bears "the material traces of its own exhibition, like scratches, that inscribe a memory within it" and its materiality causes it to chemically deteriorate over time, much like the distortion and loss of recall that can accompany aging. ${ }^{48}$ Even the DVD of the documentary manifests these filmic scars onscreen, reminding us of the fragility of retention.

However, the camera's ontological capabilities also enable Winter Soldier not only, in the words of Bill Nichols, to "describe and interpret the world of collective experience" but to participate in "the actual construction of social reality" and thus, the construction of collective memory. ${ }^{49}$ Paula Rabinowitz elaborates, stating: "Filming an essentially ephemeral event, a vanishing custom, a disappearing species, a transitory occurrence is the motivation behind most documentary images. Documentary films provide a stability to an ever-changing reality, freezing the images within their frames." ${ }^{50}$ When eleven members of the Winterfilm Collective reunite to discuss the creation of Winter Soldier in 2004, their dialogue acknowledges this desire to establish a more permanent archive out of intangible events. Roger Phenix remarks, "The fact that we caught it meant that there was a certain legitimacy ... that would have gone into thin air had it not been on film. The fact that it was on film, even though most of [the public] never even saw the film, meant that it really existed and that it was real and important." ${ }^{51}$

Thus, by providing audiovisual evidence and what Walter Benjamin calls "a simultaneous collective experience" of these testimonies, Winter Soldier constructs the memory of the event for viewers who did not attend the hearings. ${ }^{52}$ Through the act of documentation, these viewers become secondhand eyewitnesses and gain mediated but still relatively direct access to the sights and sounds of the proceedings. Comparing the cinematic experience to reading the transcript, Vogel rightly notes this film "renders academic any disputes as to the relative effectiveness of word as against image. There is simply no substitute for seeing the faces of the men as they testify, their strain, tears, hesitations, and artless innocence." ${ }^{53}$ Similarly, Roxana Waterson argues that "in films of testimony, prolonged close-ups of human faces not only provide us with an important part of the evidence (the chance to analyze non-verbal elements of communication) but also enable us as audience to do our share of the work as receptive, empathic listeners, sharing even if distantly in the event of the testifying." ${ }^{54}$ For younger generations whose collective memories of Vietnam are largely constituted by mainstream Hollywood fiction films, Winter Soldier offers an alternative, or at least additional, way to recollect the war.

\section{Reception as Metric}

Next, by analyzing the reception of Winter Soldier, I contend that reading the documentary as a kind of traumatic memory enables us to understand the vast differential of responses it has received. In 1972, when it was completed, the film was briefly shown at the Whitney Museum and for one week at the Cinema 2 in New York City, but the filmmakers could not secure wider U.S. theatrical distribution. ${ }^{55}$ Also rejected by public television stations and the three major national television networks, ${ }^{56}$ the film did air once on WNET, the PBS affiliate in New York, after a planned newsfeed did not come through. ${ }^{57}$ Winterfilm Collective member Fred Aronow reminisced, "I've heard that three million people saw Winter Soldier entirely by mistake! Unannounced!" 58 In addition, the filmmakers organized private screenings at private 
homes, community venues, and schools. ${ }^{59}$ Beyond these marginal viewings however, the film's domestic reception paralleled the reaction to the hearings themselves, which had been almost entirely ignored by national news organizations. Tellingly, Winter Soldier received a far warmer European reception in the 1970s. It played at the Cannes, Berlin, and Amsterdam Film Festivals and, as Winterfilm Collective member Bob Fiore recalls, "it was distributed throughout Europe and shown in theaters in France and in England and on television in Germany." ${ }^{\circ 0}$

Newspaper and magazine reviews from that era suggest that witnessing the testimonies, even through filmic mediation, was too distressing for many Americans. In 1972, William Wolf observed, "The memory of this documentary could well haunt you for life" and that the soldiers' stories "shake you up and are numbing in cumulative horror." ${ }^{11}$ Amos Vogel deemed watching veteran Evan Haney cry "an unbearable moment" and said, "This is a film that must be shown in prime time evening on national television and never will be." ${ }^{62}$ Jake McCarthy, in a response titled "A Film You Shouldn't See," wrote, "I've hardly ever walked out on [a movie]. I did the other night, though, because I couldn't handle it." ${ }^{63} \mathrm{He}$ reported leaving one hour into the film, explaining, "The magnitude of what has gone wrong in Vietnam has caused us to tuck the war's atrocities and terrors into our national subconscious. The film Winter Soldier trots them back out again, and the role of American GIs in the war seems to become too ugly to accept." ${ }^{64}$ As Marita Sturken notes, representations of Vietnam that were too shocking or disruptive ceded to fictionalized docudramas in which "uncomfortable histories of traumatic events can be smoothed over, retold, and ascribed new meanings." 65 Thus, to circumvent what Jonathan Schell describes as "find[ing] ourselves, almost against our will, looking through the eyes of the perpetrators" and triggering harrowing memories of the war, the documentary remained mostly unseen and commercially suppressed in the United States. ${ }^{66}$

In 2005, thirty-three years after its creation, the film received a limited U.S. theatrical release and appeared on DVD in 2006, finally making it widely viewable and available for purchase. This was largely motivated by a revived focus on Vietnam, following the Presidential nomination of John Kerry (who briefly appears in the film) in 2004 and the Swift Boat Veterans For Truth alleging that Kerry had distorted his service record and lied about troops committing atrocities. The group also issued a new challenge to the credibility of the Winter Soldier investigations, and Steve Pitkin, a veteran who appears in the documentary, filed an affidavit claiming that Kerry and others forced him to give false testimony. ${ }^{67}$ Amidst this revived battle to define the war's historiographical legacy, Winter Soldier, with its persuasive inclusion of photographic documentation of atrocities and audiovisual evidence of the hearings, was well situated to return to public consciousness.

Amidst the second Iraq War, which observers frequently compared to Vietnam and which Vietnam historian David Maraniss deemed an instance of "history repeating itself," the documentary also functioned as a record chronicling a similarly overburdened military, deceitful administration, and complicit media. ${ }^{68}$ According to the film's press kit, the Winter Soldier testimonies "eerily remind us of recent tortures and murders of prisoners held in detention by the American military. The terrible abuses of prisoners at Abu Ghraib, in Afghanistan and at Guantanamo have sometimes been reported as unprecedented. The voices of the veterans in Winter Soldier attest that they were not." ${ }^{19}$ Indeed, in March 2008, dozens of veterans convened the Winter 
Soldier: Iraq and Afghanistan investigations to testify to analogous atrocities they witnessed and committed while serving in those conflict zones. ${ }^{70}$

In 2005 , critics also largely championed the documentary's wider theatrical release, urging audiences to see the film by pronouncing it "indispensable" 71 and "essential" 72 viewing. While these critics, like their 1970s counterparts, emphasized the intense, disturbing nature of the testimonies, they expressed few of the reservations and little of the resignation evident in Vogel's or McCarthy's 1972 reviews. In her Washington Post review, Ann Hornaday stated that Winter Soldier "is an important historical document, an eerily prescient antiwar plea and a dazzling example of filmmaking at its most iconographically potent. But at its best, it is the eloquent, unforgettable tale of profound moral reckoning." "73 Some critics, expressing a similar sentiment to this article, upheld the documentary's revived potential to disabuse public misperceptions about Vietnam. For instance, Jonathan Rosenbaum, in the Chicago Reader, noted that the veterans' "simple reality exposes the well-made, Oscar-winning, racist fantasies of The Deer Hunter as unconscionable acts of self-justification and self-deception." ${ }^{74}$ Writing about Winter Soldier during the second Iraq War, critics also frequently drew parallels between Vietnam and Iraq as justifications to revisit the documentary. At least one reviewer, Johnny Ray Huston of the San Francisco Bay Guardian, did express a cynicism and weariness comparable to the 1972 critics. He predicted that the discredited accusations challenging the hearings' veracity would be another way for viewers to avoid confronting their own complicity, saying, "Nothing could be easier than to blindly state that Winter Soldier is more a work of fiction than fact. It sure would help citizens of an ethically starved and immoral country that's repeating the outrage of Vietnam to sleep easier." ${ }^{\text {T5 }}$

On one hand, the film's reappearance within this contentious new context corroborates Yael Zerubavel's notion that "collective memory continuously negotiates between available historical and current social and political agendas." ${ }^{76}$ However, conceiving of Winter Soldier as a traumatic memory also reframes atrocities in Iraq and Afghanistan as stressors that jarred the film's atrocities back into the American psyche after decades of repression. Cathy Caruth's observation that trauma "does not simply serve as record of the past but precisely registers the force of an experience that is not yet fully owned" also concretizes the documentary as a useful barometer of collective postVietnam trauma and recovery. ${ }^{77}$ Because the passage of time dilutes the controversial issues of individual and societal responsibility and dulls the intensity of collective remembrance, we can observe that the Winter Soldier testimonies are now estranged and disassociated enough to be more easily reabsorbed into public memory and employed as a historicized reference point. Yet, as the counter historical disputes of the Swift Boat controversy manifest, the Vietnam War's memorialization remains an emotional and factious battle still being waged. As the Winter Soldier: Iraq and Afghanistan testimonies also unfortunately confirm, collective American memory has only selectively acknowledged the atrocities of Vietnam thus far. It has not yet given Winter Soldier, or the veterans and casualties the documentary archives, the prominent and comprehensive remembrance they deserve. 


\section{BIBLIOGRAPHY}

Arlen, Michael J. Living-Room War. 1969; Syracuse, NY: Syracuse University Press, 1997.

Baumeister, Roy F. and Stephen Hastings. "Distortions of Collective Memory: How Groups Flatter and Deceive Themselves." In Collective Memory of Political Events: Social Psychological Perspectives, edited by James W. Pennebaker, Dario Paez, and Bernard Rimé, 277-293. Mahwah, NJ: Lawrence Erlbaum Associates, 1997.

Benjamin, Walter. "The Work of Art in the Age of Mechanical Reproduction.” In Illuminations, translated by Harry Zohn. New York: Schocken Books, 1968, 217-252.

Caruth, Cathy, ed. Trauma: Explorations in Memory. Baltimore, MD: John Hopkins University Press, 1995.

Cortright, David. "Review Essay: The Winter Soldiers Movement: GIs and Veterans Against the Vietnam War." Peace and Change 27, no. 1 (2002): 118-124.

Crandell, William. "Opening Statement of William Crandell - Winter Soldier Investigation.” The Sixties Project. http://www2.iath.virginia.edu/sixties/HTML_docs/Resources/Primary/ Winter_Soldier/WS_02_opening.html.

Duncan, Don. "Closing Statement - Winter Soldier Investigation." The Sixties Project. http:// www2.iath.virginia.edu/sixties/HTML_docs/Resources/Primary/Winter_Soldier/ WS_53_Closing.html.

Guerin, Frances and Roger Hallas, eds. The Image and the Witness. London: Wallflower Press, 2007. Hagopian, Patrick. The Vietnam War in American Memory: Veterans, Memorials, and The Politics of Healing. Ann Arbor, MI: Sheridan Books, 2009.

Hornaday, Ann. “'Soldier': Recounting Unspeakable Acts of War.” Washington Post, December 9, 2005. http://www.washingtonpost.com/wp-dyn/content/article/2005/12/08/ AR2005120800682.html.

Hunt, Andrew E. The Turning: A History of Vietnam Veterans Against the War. New York: New York University Press, 1999.

Huston, Johnny Ray. “Coldest 'Winter' Ever: A little-seen superb Vietnam doc explodes again today." San Francisco Bay-Guardian, Aug. 31 - Sept. 6, 2005. http://www.sfbg.com/39/48/ art_film_winter_soldier.html.

Iraq Veterans Against the War and Aaron Glantz. Winter Soldier: Iraq and Afghanistan: Eyewitness Accounts of the Occupations. Chicago: Haymarket Books, 2008.

Jay, Jeffrey A. “After Vietnam: In Pursuit of Scapegoats.” Harper's Magazine, July 1978.

Kemp, Janet and Robert Bossarte. "Suicide Data Report - 2012." U.S. Department of Veterans Affairs Mental Health Services, 2012. http://www.va.gov/opa/docs/Suicide-Data-Report-2012-final.pdf.

Kerry, John. "Vietnam Veterans Against the War Statement by John Kerry to the Senate Committee Foreign Relations - April 23, 1971.” The Sixties Project. http://www2.iath.virginia.edu/ sixties/HTML_docs/Resources/Primary/Manifestos/VVAW_Kerry_Senate.html.

Klawans, Stuart. "Eat The Document.” The Nation, August 29, 2005. 
Klein, Michael. "Historical Memory, Film, and the Vietnam Era." In From Hanoi to Hollywood: The Vietnam War in American Film, edited by Linda Dittmar and Gene Michaud, 19-40. New Brunswick, NJ: Rutgers University Press, 1990.

Knoll, Erin and Judith Nies McFadden, eds. War Crimes and the American Conscience. New York: Holt, Rinehart and Winston, 1970.

Kowal, Jessica. “'Welcome to Vietnam, Mr. President.” Salon, November 17, 2003. http:// www.salon.com/2003/11/17/iraq_viet.

Krystal, John H., Steven M. Southwick, and Dennis S. Charney. "Post Traumatic Stress Disorder: Psychobiological Mechanisms of Traumatic Remembrance." Memory Distortion: How Minds, Brains, and Societies Reconstruct the Past, edited by In Daniel L. Schacter, 150-172. Cambridge, MA: Harvard University Press, 1995.

Lachman, Elly. “Winter Soldier Press Kit,” PDF on Winter Soldier DVD, 2005.

Laderman, Scott. Tours of Vietnam: War, Travel Guides, and Memory. Raleigh, NC: Duke University Press, 2009.

Lanzmann, Claude. "Le lieu et la parole." In Au sujet de Shoah: Le Film de Claude Lanzmann, edited by Michel Deguy, 293-305. Paris: Belin, 1990.

Mandelbaum, Michael. “Vietnam: The Television War.” Daedalus 111, no. 4 (1982): 157-169.

Marin, Peter. “Coming to terms with Vietnam: Settling our moral debts.” Harper's Magazine, December 1980.

McCarthy, Jake. “A Film You Shouldn't See.” St. Louis Post-Dispatch, October 23, 1972. Winter Soldier Film. http://wintersoldierfilm.com/reviews_102372_stlouis.htm.

Morag, Raya. "Perpetrator Trauma and Current Israeli Documentary Cinema." Camera Obscura 80, vol. 27, no. 2 (2012): 92-133.

Moser, Richard. The New Winter Soldiers: GI and Veteran Dissent During the Vietnam Era. New Brunswick, NJ: Rutgers University Press, 1996.

Nelson, Craig. Thomas Paine: Enlightenment, Revolution, and the Birth of Modern Nations. New York: Penguin Books, 2006.

Nichols, Bill. Representing Reality. Bloomington, IN: Indiana University Press, 1991.

Nicosia, Gerald. Home to War: A History of the Vietnam Veterans' Movement. New York: Carroll \& Graf Publishers, 2001.

Paine, Thomas. The American Crisis. 1776; Philadelphia, PA: Styner and Cist, 1776- 1777.

Pennebaker, James W. and Becky L. Banasik. "On the Creation and Maintenance of Collective Memories: History as Social Psychology." In, eds, Collective Memory of Political Events: Social Psychological Perspectives, edited by James W. Pennebaker, Dario Paez, and Bernard Rimé, 3-19. Mahwah, NJ: Lawrence Erlbaum Associates, 1997.

Rabinowitz, Paula. "Wreckage Upon Wreckage: History, Documentary and the Ruins of Memory." History and Theory 32, no. 2 (1993): 119-137.

Rosenbaum, Jonathan. “Arms and the Men.” Chicago Reader, September 16, 2005. http:// www.chicagoreader.com/chicago/arms-and-the-men/Content?oid=919893.

Schell, Jonathan. "The Talk of the Town: Notes and Comment." New Yorker, December 20, 1969. 
Schudson, Michael. Watergate in American Memory: How We Remember, Forget, and Reconstruct the Past. New York: Basic Books, 1992.

Schwenkel, Christina. The American War in Contemporary Vietnam: Transnational Remembrance and Representation. Bloomington, IN: Indiana University Press, 2009.

Silverstone, Roger. "Complicity and collusion in the mediation of everyday life." New Literary History 33 (2002): 761-780.

Stacewicz, Richard. Winter Soldiers: An Oral History of the Vietnam Veterans Against The War. New York: Twayne Publishers, 1997.

Sturken, Marita. Tangled Memories: The Vietnam War, The AIDS Epidemic, and the Politics of Remembering. Berkeley, CA: University of California Press, 1997.

Turner, Fred. Echoes of Combat: The Vietnam War in American Memory. New York: Anchor Books, 1996.

Vogel, Amos. “Atrocities and Artless Innocence.” Village Voice, February 3, 1972. Winter Soldier Film. http://wintersoldierfilm.com/reviews_020372_voice.htm.

Waterson, Roxana. "Trajectories of Memory: Documentary Film and the Transmission of Testimony." History and Anthropology 18, no. 1 (2007): 51-73.

Westheider, James E. Fighting on Two Fronts: African Americans and the Vietnam War. New York: New York University Press, 1997.

Willis, Sharon. "Lost Objects: The Museum of Cinema." In The Renewal of Cultural Studies, edited by Paul Smith, 93-102. Philadelphia, PA: Temple University Press, 2011.

Wilson, Ron. “Review: Winter Soldier (1972).” The Moving Image 7, no. 1 (2007): 122-124.

Wolf, William. “Winter Soldier Review.” Cue Magazine, May 13, 1972. Winter Soldier Film. http:// wintersoldierfilm.com/reviews_051372_cue.htm.

Zerubavel, Yael. Recovered Roots: Collective Memory and the Making of Israeli National Tradition. Chicago: University of Chicago Press, 1995.

\section{Filmography}

A Conversation with the Filmmakers (Michael Lesser, 2005). Bonus feature on Winter Soldier DVD.

The Deer Hunter (Michael Cimino, 1978).

Winter Soldier (Winterfilm Collective, 1972).

\section{NOTES}

1. Winter Soldier, directed by Winterfilm Collective (1972; Harrington Park, NJ: Milliarium Zero, 2006), DVD. All of the quotations without citations in this article, such as the one by Shimabukuro, are direct quotes from this documentary.

2. Don Duncan, "Closing Statement - Winter Soldier Investigation," The Sixties Project, http:// www2.iath.virginia.edu/sixties/HTML_docs/Resources/Primary/Winter_Soldier/ WS_53_Closing.html.

3. Andrew E. Hunt, The Turning: A History of Vietnam Veterans Against the War (New York: New York University Press, 1999), 68. 
4. Demonstrating the imprecise nature of historiography, writers and historians have documented the number of testifiers at these hearings as "a little over 100 veterans" (Nicosia 87), "more than one hundred veterans and sixteen civilians" (Hunt 71), "more than 125 veterans" (Lachman 3), "150 veterans" (Hagopian 53 and Stacewicz 234), "200 young veterans" (McCarthy), and "more than 200 ex-GIs" (Vogel). Reviewing the hearing transcripts in their entirety, I counted 132 individuals who testified-116 veterans and 16 civilians. Perhaps confounding the inexactitude, the transcript also occasionally attributes remarks to an "Unidentified Panelist" or "Panelist," not clarifying if additional people testified but were not credited or if the record did not document which of the previously credited panelists made these remarks. A full transcription of the Winter Soldier hearings can be found at The Sixties Project at http:// www2.iath.virginia.edu/sixties/HTML_docs/Resources/Primary/Winter_Soldier/WS_entry.html and as a PDF on the Winter Soldier DVD. Senator Mark Hatfield also added the entirety of the remarks into the Congressional Record as Extensions and Remarks 2825-2900, 2903-2936 on April 7, 1971.

5. John Kerry, "Vietnam Veterans Against the War Statement by John Kerry to the Senate Committee Foreign Relations - April 23, 1971," The Sixties Project, http://www2.iath.virginia.edu/ sixties/HTML_docs/Resources/Primary/Manifestos/VVAW_Kerry_Senate.html.

6. Elly Lachman, “Winter Soldier Press Kit," PDF on Winter Soldier DVD, 2005, 5, 3.

7. Richard R. Moser, The New Winter Soldiers: GI and Veteran Dissent During the Vietnam Era (New Brunswick, NJ: Rutgers University Press, 1996), 2.

8. Some of these works are Patrick Hagopian's The Vietnam War in American Memory: Veterans, Memorials, and The Politics of Healing (Ann Arbor, MI: Sheridan Books, 2009); Scott Laderman's Tours of Vietnam: War, Travel Guides, and Memory (Raleigh, NC: Duke University Press, 2009); and Christina Schwenkel's The American War in Contemporary Vietnam: Transnational Remembrance and Representation (Bloomington, IN: Indiana University Press, 2009).

9. Examples of this application can be found in Marita Sturken's Tangled Memories: The Vietnam War, The AIDS Crisis, and the Politics of Remembering (Berkeley, CA: University of California Press, 1997); Michael Klein's article "Historical Memory, Film, and the Vietnam Era" in Linda Dittmar and Gene Michaud, eds., From Hanoi to Hollywood: The Vietnam War in American Film (New Brunswick, NJ: Rutgers University Press, 1990); and Fred Turner's Echoes of Combat: Trauma, Memory, and the Vietnam War (New York: Anchor Books, 1996).

10. Paula Rabinowitz, "Wreckage Upon Wreckage: History, Documentary and the Ruins of Memory," History and Theory 32, no. 2 (1993): 119.

11. This new wave of scholarship includes the aforementioned The New Winter Soldiers by Moser and The Turning by Hunt, as well as Richard Stacewicz's Winter Soldiers: An Oral History of the Vietnam Veterans Against the War (New York: Twayne Publishers, 1997) and Gerald Nicosia's Home to War: A History of the Vietnam Veterans' Movement (New York: Carroll \& Graf Publishers, 2001).

12. David Cortright, "Review Essay: The Winter Soldiers Movement: GIs and Veterans Against the Vietnam War," Peace and Change 27, no. 1 (2002): 119.

13. For one discussion of the similarities and differences between Iraq and Vietnam, see Jessica Kowal's “'Welcome to Vietnam, Mr. President," Salon, November 17, 2003, http:// www.salon.com/2003/11/17/iraq_viet.

14. Janet Kemp and Robert Bossarte, "Suicide Data Report - 2012," U.S. Department of Veteran Affairs Mental Health Services, 18. http://www.va.gov/opa/docs/Suicide-Data-Report-2012final.pdf.

15. James W. Pennebaker and Becky L. Banasik, "On the Creation and Maintenance of Collective Memories: History as Social Psychology.” In James W. Pennebaker, Dario Paez, and Bernard Rimé, eds, Collective Memory of Political Events: Social Psychological Perspectives (Mahwah, NJ: Lawrence Erlbaum Associates, 1997), 7.

16. Pennebaker and Banasik, "On the Creation and Maintenance of Collective Memories", 8. 
17. Pennebaker and Banasik, "On the Creation and Maintenance of Collective Memories", 11.

18. John H. Krystal, Steven M. Southwick, and Dennis S. Charney, "Post Traumatic Stress Disorder: Psychobiological Mechanisms of Traumatic Remembrance" in Daniel L. Schacter, ed, Memory Distortion: How Minds, Brains, and Societies Reconstruct the Past (Cambridge, MA: Harvard University Press, 1995), 150.

19. Turner, Echoes of Combat, 18.

20. Raya Morag, "Perpetrator Trauma and Current Israeli Documentary Cinema," Camera Obscura 80, vol. 27, no. 2 (2012): 93.

21. Morag, "Perpetrator Trauma and Current Israeli Documentary Cinema," 95.

22. Michael J. Arlen, Living Room-War (Syracuse, NY: Syracuse University Press, 1997), 6.

23. Michael Mandelbaum, "Vietnam: The Television War," Daedalus 111, no. 4 (1982): 157, 161.

24. Roger Silverstone, "Complicity and collusion in the mediation of everyday life," New Literary History 33 (2002): 774.

25. Peter Marin, "Coming to Terms with Vietnam: Settling Our Moral Debts," Harper's Magazine, December 1980, 42.

26. Jeffrey A. Jay, “After Vietnam: I. In Pursuit of Scapegoats,” Harper's Magazine, July 1978, 14.

27. Robert Jay Lifton quoted in Erwin Knoll and Judith Nies McFadden, eds., War Crimes and the American Conscience (New York: Holt, Rinehart and Winston, 1970), 107-108.

28. Roy F. Baumeister and Stephen Hastings, "Distortions of Collective Memory: How Groups Flatter and Deceive Themselves" in Collective Memory of Political Events: Social Psychological Perspectives, 282-283.

29. Stacewicz, Winter Soldiers, 5.

30. Thomas Paine, The American Crisis (Philadelphia, PA: Styner and Cist, 1776-1777). An image of the text is here: http://www.indiana.edu/ liblilly/history/american-crisis.html.

31. William Crandell quoted in Nicosia, 79.

32. Turner, Echoes of Combat, 21.

33. William Cobbett quoted in Craig Nelson, Thomas Paine: Enlightenment, Revolution, and the Birth of Modern Nations (New York: Penguin Books, 2006), 5.

34. Nelson, Thomas Paine, 8, 10.

35. James E. Westheider, Fighting on Two Fronts: African Americans and the Vietnam War (New York: New York University Press, 1997), 13, 20, 12.

36. Winterfilm Collective, "Remarks by the filmmakers providing a brief historical context for viewing Winter Soldier," PDF on Winter Soldier DVD, 2006, 1.

37. William Crandell, "Opening Statement of William Crandell - Winter Soldier Investigation," The Sixties Project, http://www2.iath.virginia.edu/sixties/HTML_docs/Resources/Primary/ Winter_Soldier/WS_02_opening.html.

38. Sturken, "Tangled Memories," 82, 62.

39. Don Donner quoted in " $1^{\text {st }}, 4^{\text {th }}$, and $9^{\text {th }}$ Infantry Divisions - Winter Soldier Investigation," The Sixties Project,

http://www2.iath.virginia.edu/sixties/HTML_docs/Resources/Primary/Winter_Soldier/

WS_45_1Infantry.html.

40. Kerry, "Vietnam Veterans Against the War Statement."

41. Like the discrepancies concerning the number of people testifying, it is revealing how the number of credited filmmakers fluctuates in historical accounts and reviews. For example, an intertitle in the DVD bonus feature A Conversation With the Filmmakers represents the number of Winterfilm Collective members as "about 17," Nicosia attributes the documentary to "fifteen peace activists" (84), and Stacewicz simply credits "an independent filmmaker" (267). I have taken the count of nineteen from the Winter Soldier Press Kit, which lists all nineteen members.

42. A Conversation with the Filmmakers, directed by Michael Lesser (2005; Harrington Park, NJ: Milliarium Zero, 2006), bonus feature on Winter Soldier DVD. 
43. A Conversation with the Filmmakers.

44. Michael Schudson, Watergate in American Memory: How We Remember, Forget, and Reconstruct the Past (New York: Basic Books, 1992), 51-52.

45. Claude Lanzmann, "Le lieu et la parole," in Au sujet de Shoah: Le Film de Claude Lanzmann, ed. Michel Deguy (Paris: Belin, 1990), 304.

46. Amos Vogel, "Atrocities and Artless Innocence" from Village Voice, February 3, 1972, Winter Soldier Film, http://wintersoldierfilm.com/reviews_020372_voice.htm.

47. Frances Guerin and Roger Hallas, introduction to The Image and the Witness, eds. Frances Guerin and Roger Hallas (London: Wallflower Press, 2007), 2.

48. Sharon Willis, "Lost Objects: The Museum of Cinema," in The Renewal of Cultural Studies, ed. Paul Smith (Philadelphia, PA: Temple University Press, 2011), 93-94.

49. Bill Nichols, Representing Reality (Bloomington, IN: Indiana University Press, 1991), 10.

50. Rabinowitz, "Wreckage Upon Wreckage," 120.

51. A Conversation with the Filmmakers.

52. Walter Benjamin, "The Work of Art in the Age of Mechanical Reproduction" in Illuminations, trans. Harry Zohn (New York: Harcourt Brace Jovanovich, 1968), 234.

53. Vogel, "Atrocities and Artless Innocence."

54. Roxana Waterson, "Trajectories of Memory: Documentary Film and the Transmission of Testimony," History and Anthropology 18, no. 1 (2007): 70.

55. Lachman, "Winter Soldier Presskit," 3.

56. Ron Wilson, “Review: Winter Soldier (1972)" from The Moving Image 7, no. 1 (2007): 123.

57. Wilson, "Review: Winter Soldier (1972)," 123.

58. A Conversation with the Filmmakers.

59. Winterfilm Collective, 3 .

60. Winterfilm Collective, 3 .

61. William Wolf, "Winter Soldier Review," from Cue Magazine, May 13, 1972, Winter Soldier Film, http://wintersoldierfilm.com/reviews_051372_cue.htm.

62. Vogel, "Atrocities and Artless Innocence."

63. Jake McCarthy, "A Film You Shouldn't See" from St. Louis Post-Dispatch, October 23, 1972, Winter Soldier Film,

http://wintersoldierfilm.com/reviews_102372_stlouis.htm.

64. McCarthy, “A Film You Shouldn't See."

65. Sturken, "Tangled Memories," 85.

66. Jonathan Schell, “The Talk of the Town: Notes and Comment," New Yorker, December 20, 1969, 27.

67. Johnny Ray Huston, “Coldest "Winter" Ever: A little-seen superb Vietnam doc explodes again today," San Francisco Bay-Guardian, August 31 - September 6, 2005, http://www.sfbg.com/39/48/ art_film_winter_soldier.html.

68. Kowal, "Welcome to Vietnam."

69. Lachman, "Winter Soldier Presskit," 3.

70. Iraq Veterans Against the War and Aaron Glantz, Winter Soldier: Iraq and Afghanistan: Eyewitness Accounts of the Occupations (Chicago: Haymarket Books, 2008), 6.

71. Stuart Klawans, "Eat The Document," The Nation, August 29, 2005, 42.

72. Jonathan Rosenbaum, "Arms and the Men," Chicago Reader, September 16, 2005, http:// www.chicagoreader.com/chicago/arms-and-the-men/Content?oid=919893.

73. Ann Hornaday, “'Soldier': Recounting Unspeakable Acts of War," Washington Post, December 9 , 2005, http://www.washingtonpost.com/wp-dyn/content/article/2005/12/08/ AR2005120800682.html.

74. Rosenbaum, "Arms and the Men."

75. Huston, “Coldest 'Winter' Ever." 
76. Yael Zerubavel, Recovered Roots: Collective Memory and the Making of Israeli National Tradition (Chicago: University of Chicago Press, 1995), 5.

77. Cathy Caruth, introduction to Trauma: Explorations in Memory, ed. Cathy Caruth (Baltimore, MD: John Hopkins University Press, 1995), 151.

\section{ABSTRACTS}

This article examines the 1972 Vietnam War documentary Winter Soldier (The Winterfilm Collective), the only remaining public audiovisual record of the momentous 1971 Winter Soldier investigation, through the lens of memory. It considers textual appearances of repressed and traumatic memories and how they stand in for larger national and institutional repressions. It also theorizes how the film and the event it documents constitute forms of collective memories. Finally, the article looks at the film's troubled reception and commercial suppression in 1972 and finally, its return to public consciousness in 2005 as a metric of national traumatization and recovery.

\section{INDEX}

Keywords: Vietnam War, documentary, memory, atrocity, trauma

\section{AUTHOR}

\section{DANIEL GRINBERG}

Daniel Grinberg is a graduate student and associate instructor studying Film and Media in the Department of Communication and Culture at Indiana University. His current research focuses on war documentaries, particularly through the lenses of memory and spatiality, as well as postcolonial representations of colonial histories and digital dissidence in repressive regimes. Some of his upcoming projects will interrogate gendered spaces in Vietnam War documentaries and the state repression of Octobre à Paris (Jacques Panijel, 1962), a film memorializing the 1961 French police massacre of Algerian demonstrators. 